\title{
Deposition of airborne fungal diaspores on special agar plates in Finland 1967-1968
}

\author{
Tauno Kallio
}

Department of Plant Pathology, University of Helsinki

\begin{abstract}
The deposition of fungal diaspores was investigated from samples collected mainly from airfields throughout Finland in the period from June 7, 19.6.7 to May 29, 1968. The number of colonies which had grown from the diaspores after 10 days in the laboratory were counted from agar plates, but no attempt was made to identify the fungi. In 1968, samples were taken in three spruce (Picea abies (L.) Karst.) stands of South Finland throughout 24 hour periods at weekly or fortnightly intervals. The correlation of diaspore deposition with weather elements was statistically analysed.
\end{abstract}

\section{Introduction}

Aerial distribution of fungi has been studied by e.g. HANSEN (1882), Rostrup (1908), GREGORY (1945, 1952 a, b, 1961), and Hirst etal. (1967 a, b). Especially the airborne spores of fungi causing allergy in man have been intensively studied in the last decades (Feinberg and Litrte 1936, Durham 1938, Bernstein and Feinberg 1942). Rishbeth (1951) found that the fungus causing root and butt rot (Fomes annosus (Fr.) Cooke) was aerially distributed to the cut surfaces of healthy and fresh stumps of the pine (Pinus silvestris L.), and thense into roots and other trees. After RisHвETH's report, intense research was started in several countries into the aerial distribution of $F$. annosus (Molin 1957, MrLler 1960, YDE-ANDERSEN 1961, Dimitri 1963, Sinclair 1964, Kallio 1965, 1970, Reynolds and Wallis 1966, Drummond and Bretz 1967).

The present study was carried out in connection with another study into the aerial distribution of $F$. annosus in 1967-68 (KALLIO 1970). The purpose was to study the aerial diaspore deposition of unidentified fungi capable of growing on certain growth substrates, and the correlations of this deposition with weather elements.

\section{Materials and methods Growth substrates}

The study was divided into two parts: a preliminary and a main study. The preliminary study used two growth substrates, both developed for $F$. annosus studies. Kunlman and Hendrix (1962) developed a substrate containing streptomycin and PCNB; this substrate - working name $\mathrm{K}$ agar - was one of the two used in the present study. The other was the agar substrate developed by Kuhlman (1966) for studies of the root rot fungus - working name $\mathrm{H}$-agar. The latter contains penicillin and PCNB. The main study used only $\mathrm{H}$-agar substrates. According to studies by the above authors who developed the substrates, a number of fungi will not grow on these substrates.

\section{Observation places and times Preliminary study}

The substrates weres exposed on six open sites in various parts of Finland (Fig. 1) in 
the period from June 7, 1967 to May 29, 1968. The observation places on open sites were the meteorological stations of Ivalo, Oulu, Jyväskylä, Lappeenranta and Turku airfields, and a meteorological station in Helsinki (Viikki). An observation place in a forest site was located in Helsinki (Viikki). On these the substrates were exposed to aerial deposition of diaspores on given days at hours which the staff of the meteorological stations found to be convenient. The substrates were exprosed simultaneously. On each observation site, there were three $\mathrm{H}$-agar and three $\mathrm{K}$-agar substrates which had been prepared in palstic dishes, diameter $88 \mathrm{~mm}$ (surface area $61 \mathrm{sq} . \mathrm{sm}$ ), and been inserted into plastic bags. Ome $\mathrm{H}$-agar and one $\mathrm{K}$-agar substrate were controls and were never exposed. The lids of the other two dishes were opened simultaneously. One was exposed for $5 \mathrm{~min}$ utes, the other for 10 minutes. After expo-

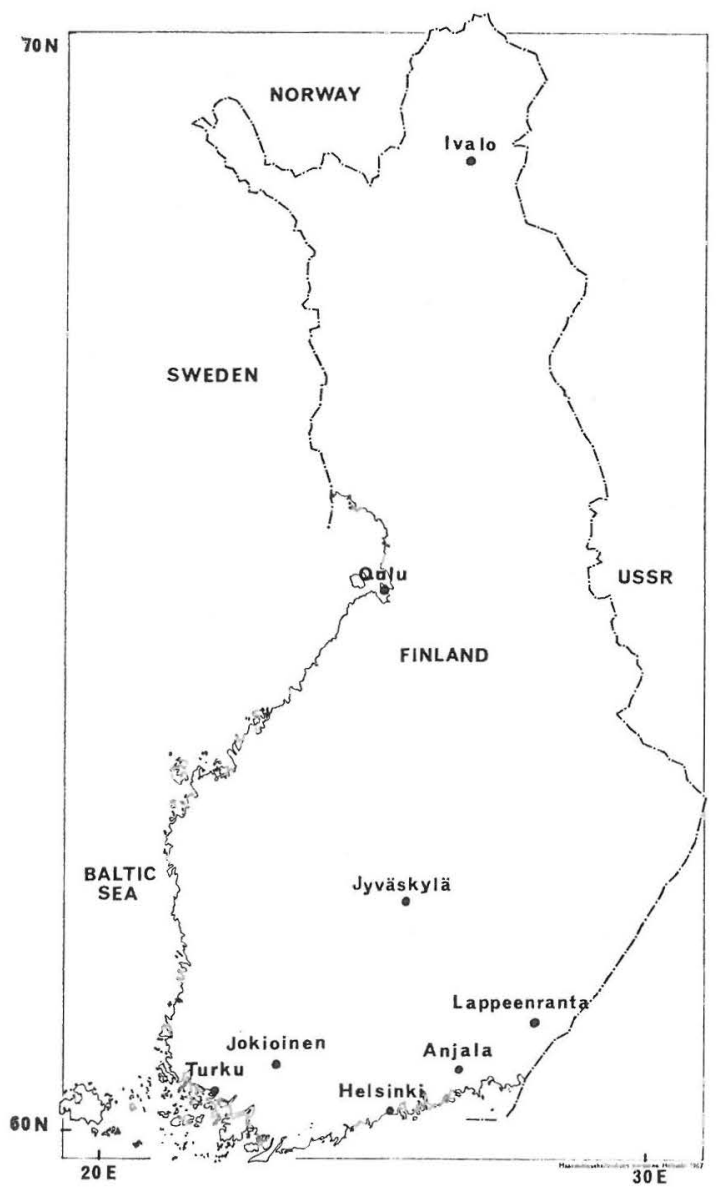

Fig. 1. Observation places. sure the substrates from the outlying sites were airmailed to Helsinki and all samples were kept in the laboratory there.

\section{Main study}

The principal observation places were Picea abies (L.) Karst. stands in Helsinki (Viikki), Anjala and Jokioinen (Fig. 1). The dishes were exposed on a plate lying on the ground. Observations were made throughout the year 1968. The 24-hour observation day started on Wednesday at 13.15 and ended on Thursday at 13.15. In Helsinki the observation day between March 13 and December 5 occurred once a week, otherwise once a fortnight. The $\mathrm{H}$-agar substrates, from January 3 to June 20, and from October 2 to December 19, were exposed for 5 minutes beginning on Wednesday at 13.15, 15.15, 17.15 and so on at 2-hour intervals until the 5 -minute period beginning on Thursday at 11.15. From June 26 to September 26 the duration of exposure alternated between one and 5 minutes, the substrates being exposed for 5 minutes durink tre day and for 1 minute during the night.

At Anjala and Jokioinen, the 24-hour observation day from January 3 to December 19 occurred once a fortnight. The substrates were exposed for 5 minutes at 2-hour intervals beginning at 13.15 on Wednesday and ending with the 5 minute period that started at 11.15 on Thursday. The substrates were mailed to and from the observation places. Due to irregularities in transportation the observation day at Anjala fell on June 2021 while at Helsinki and Jokioinen it was June 19-20. For the same reason the observation day at Jokioinen fell on December 19 - 20 while at Helsinki and Anjala it was on December 18-19.

The main study collected a number of supplementary observations on diaspore deposition in the various places, and they will be reported in detail in the relevant contexts.

\section{Weather elements}

Weather observations for the main study were carried out in Helsinki alone. From the records of the Meteorological Institute's stations at Viikki and at Malmi airfield, data 
concerning air temperature, precipitation, sunshine sum, the difference between the maximum and minimum atmospheric pressures during the observation day, and wind velocity were used for the study. They were obtained from tables calculated by the $\mathrm{Me}$ teorological Institute. A recording thermometer and hygrometer (model Lambrecht No. 252, weekly graph) were used to measure temperatures and air humidities in the forest in Helsinki in the immediate neighbourhood of the site of diaspore deposition, at a height of 2 metres from ground level. The Viikki meteoroligical station was about $1 \mathrm{~km}$ and Malmi airfield about $4 \mathrm{~km}$ from the place where the diaspore deposition was measured.

\section{Results \\ Preliminary study}

After exposure, the $\mathrm{H}$-and $\mathrm{K}$-agar substrates were kept in the laboratory in plastic bags for 10 days. After this the colonies on fungal growth were counted from the substrates, excluding the $F$. annosus colonies. The number of colonies was indicated per 100 sq.cm. of exposed surface per hour.

The diaspore deposition varies according to the time of day or night (Nilsby 1949, Gregory and Sreeramulu 1958, Harvey et al. 1969, PADY et al. 1969). Since the substrates were not exposed simultaneously, a comparison of the depositions at different hours is not feasible. Table 1 gives the monthly mean values on the different observation places; the mean values were calculated from the total depositions on the $\mathrm{H}$ - and $\mathrm{K}$-agar substrates. Some substrates carried so many colonies that their exact number could not be counted. In these cases the table indicates that colonies were more numerous than is shown by the numeral of the table. In January-March the diaspore deposition was scantier than in the other seasons. The finding agrees with those reported by many authors (e.g. HYDE and WILliams 1946, 1953, RenNerfelt 1947, Nilsby 1949, Riahards 1954, a, 1954 b). The deposition was particularly light during this period at the Ivalo and Oulu airfield meterological stations, in Ivalo scantier than anywhere else in the country.

\section{Main study}

The diaspore deposition is illustrated by the graph of Fig. 2. The minimum deposition was in January-March, and it was also relatively scanty in the autumn, November-December. The result agrees with that of the preliminary study. The deposition was most profuse from late May to mid-September. Figs. 3-6 specify the depositions of a few observation days at the various observation places by hours of day and night. At the end of April (Fig. 3) no distinct diurnal rhythm could be observed, even though Helsinki and Jokjoinen showed distinct deposition peaks at night and in the morning. In late June (Fig. 4) a distinct maximum was noted in Helsinki in the middle of the night and another time of profuse deposition in the early hours of the morning (cf. RicH and WAGgoner 1962). At Anjala and Jokioinen also the deposition increased in the middle of the night. The middle of August (Fig. 5) the deposition in the early morning hours was profuse at Helsinki and Jokioinen.

Table 1. Total diaspore settling $1967-1968$, spores $/ 100 \mathrm{~cm}^{2} / \mathrm{hr}$.

\begin{tabular}{|c|c|c|c|c|c|c|c|c|c|c|c|c|}
\hline \multirow[b]{2}{*}{$\begin{array}{l}\stackrel{0}{J} \\
\frac{\pi}{\Xi}\end{array}$} & \multicolumn{7}{|l|}{1967} & \multicolumn{5}{|c|}{1968} \\
\hline & $\stackrel{\Xi}{\Xi}$ & $\frac{2}{3}$ & $\begin{array}{l}\vec{\omega} \\
\vec{J} \\
0 \\
\vec{z}\end{array}$ & 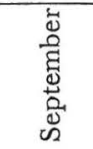 & $\begin{array}{l}\dot{0} \\
\tilde{0} \\
\tilde{0} \\
0\end{array}$ & 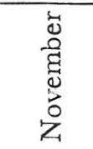 & 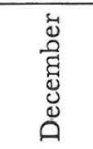 & 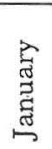 & 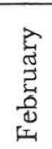 & 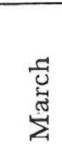 & 营 & 㥑 \\
\hline Helsinki, forest & $>361$ & $>456$ & $>208$ & $>468$ & $>361$ & $>198$ & $>164$ & 37 & 15 & 5 & $>558$ & 239 \\
\hline Helsinki, field & $>292$ & $>270$ & $>491$ & $>298$ & $>315$ & 109 & 180 & 58 & 2 & 14 & $>410$ & 103 \\
\hline Turku & 124 & 170 & 381 & 161 & 180 & $>150$ & 4 & 71 & 2 & 36 & 305 & 150 \\
\hline Jyväskylä & $>240$ & $>380$ & $>445$ & $>282$ & 152 & 70 & 170 & 12 & 12 & 25 & 161 & 125 \\
\hline Lappeenranta & 191 & $>347$ & $>325$ & 116 & $>208$ & 48 & $>199$ & 25 & 23 & 102 & 88 & 288 \\
\hline Oulu & $>259$ & $>198$ & $>181$ & $>267$ & 43 & 81 & 192 & 69 & 1 & 3 & 10 & $>85$ \\
\hline Ivalo & $>93$ & 150 & $>171$ & 89 & 2 & 13 & 7 & 0 & 2 & 9 & 8 & 28 \\
\hline
\end{tabular}




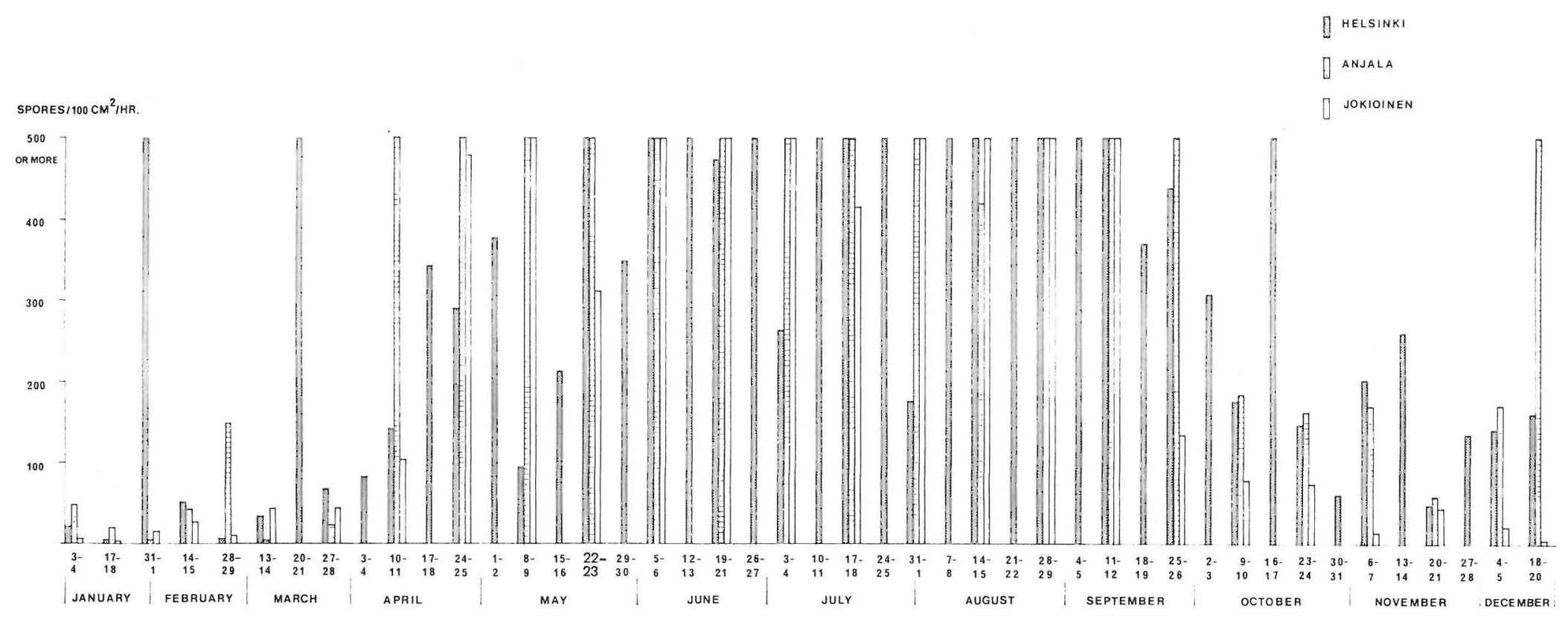

Fig. 2. Total diaspore settling 1968 in Helsinki, Anjala, and Jokioinen. 
t)
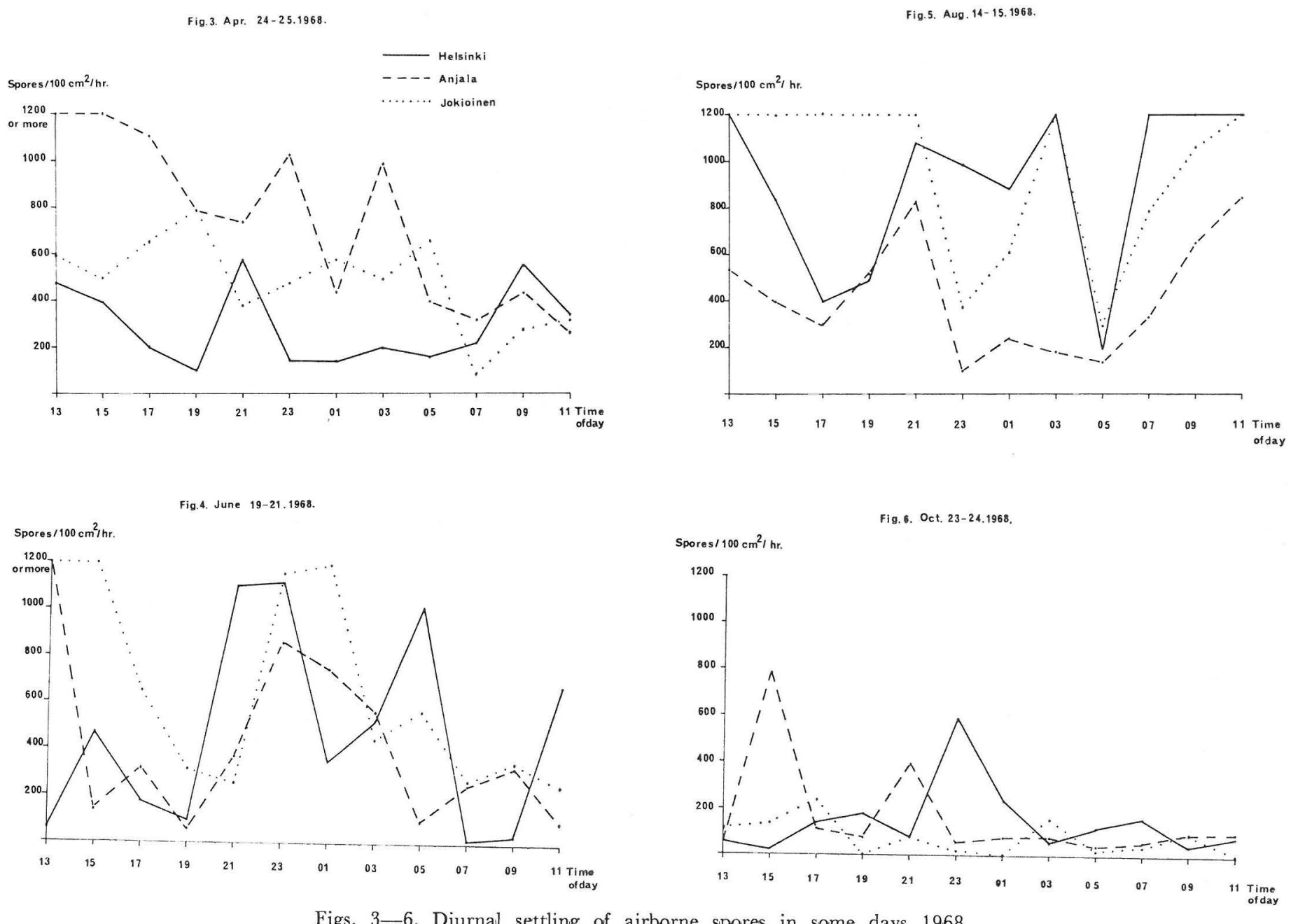

Figs. 3-6. Diurnal settling of airborne spores in some days 1968. 
Table 2.

Correlation coefficients between total diaspore settling and some weather elements in Helsinki 1968.

Weather element

The hole year

Jan. 3 - Mar. 28

Apr. 3 - May 30

Jun. 5 - Sep. 26

Oct. 2 - Dec. 19

Weather element

The hole year

Jan. 3 - Mar. 28

Apr. 3 - May 30

Jun. 5 - Sep. 26

Oct. 2 - Dec. 19

$\quad 1$
$0.274+++$
0.071
0.126
$0.219++$
$0.178+$

\section{8}

$0.111++$

0.000

0.202
0.077

0.167

$$
2
$$

$0.264+++$

0.129

0.027

0.094

0.109

9

\subsection{9}

0.000
$0.360++$

$0.360++$
$-0.183++$

$0.281++$
-

\begin{abstract}
3
\end{abstract}

$0.108+$
$0.216+$
0.070
0.056
0.100

0.100

\section{0}

$0.274+++$
0.099
0.216

$0.216++$

$0.184+$

$\quad 4$
$0.220+++$
$0.279++$
0.088
$0.310+++$
$0.250++$

$$
5
$$

0.064$$
\begin{aligned}
& 0.000 \\
& 0.268+
\end{aligned}
$$$$
\begin{array}{r}
0.268 \\
-0.009
\end{array}
$$$$
\begin{array}{r}
-0.009 \\
-0.057
\end{array}
$$

\section{1}

$0.257+++$

0.127

0.042

0.106

0.024

$\begin{array}{cc}6 & 7 \\ 0.047 & 0.071 \\ 0.000 & 0.000 \\ 0.033 & 0.300++ \\ -0.054 & 0.065 \\ -0.011 & -0.002\end{array}$

1. Mean air temperature on open site $\left({ }^{\circ} \mathrm{C}\right.$, at 2 meters above ground level) of the 5 calendar days preceding the day of observation.

2. Mean air temperature (measured as above) of the calendar days on which the 24-hour observation period was divided.

3. Total precipitation $(\mathrm{mm})$ during the 5 calendar days preceding the day of observation.

4. Total precipitation $(\mathrm{mm})$ of the 2 calendar days on which the 24 -hour observation period was divided.

5. Hour of bright sunshine during the 5 calendar days before observation day on open site.

6. Houns of bright sunshine during 24-hour observation day on open site.

7. Wind velocity $(\mathrm{m} / \mathrm{sec}$.) during the 24 -hour observation, by recording periods at the Malmi aeronautical meteorological station.

8. Wind velocity ( $\mathrm{m} / \mathrm{sec}$.) mean of the 24-hour observation, at the Malmi aeronautical meteorological station.

9. Difference between the maximum and minimum atmospheric pressure readings on the observation day at the Malmi aeronautical meteorological station.

10. Air temperature by 2-hour periods of the 5 preceding days, at 2 meters above ground level in the forest.

11. Air temperature (measured as above) of 24-hour observation.

12. Air huminity (measured as above) of the 5 preceding days.

13. Air humidity (measured as above) of 24-hour observation.

Significant at the level: $+\mathrm{P} \leqq 0.05,++\mathrm{P} \leqq 0.01,+++\mathrm{P} \leqq 0.001$. 
However, almost the only feature shared by all three places of observation was that the lightest falls occurred late in the evening and early in the morning. At the end of October (Fig. 6) the deposition was scantier than in the summer and early autumn. At Anjala the maximum was noted in the afternoon and in Helsinki at midnight. The diurnal rhythm of deposition in the different seasons of the year was therefore different. Generally, however, in May-September more diaspores were caught during the night than the day. A similar result has been reported e.g. by Hirst (1953), Gregory and SreeraMulu (1958), Pathak and Pady (1965), Walkey and Harvey (1966), Hodgkiss and Harvey (1969), Pady and Kramer (1969), and PADY et al. (1969a).

Table 2 presents correlation coefficients between the diaspore deposition and a few weather elements in Helsinki. Mainly on the basis of the profusion of diaspore depostition, the year was divided into four parts. Correlation coefficients were separately calculated for the whole year and for each part. The diaspore deposition for the whole year was a highly significant positive correlation with air temperature recorded at a 2-metre height on open sites and in the forest, and with the precipitation sum measured on open sites. A similar correlation with air temperatur was reported by Sinclair (1964). In JanuaryMarch the most pronounced positive correlation (significance below 1 per cent) was noted with the precipitation sum. In AprilMay the diaspore deposition was highly significantly negatively correlated with air humidity recorded in the forest at 2 metres from the ground. PADY et al. (1969b) reported that the spore liberation of the Cladosporium fungi was correlated positively with temperature rise and negatively with reduction in the relative air humidity. In Helsinki, in the season of the most profuse diaspore deposition from June to September, the diaspore deposition was highly significantly positively correlated with the precipitation sum of the 24-hour observation day. A similar result was reported e.g. by Hodgkiss and HaRvey (1969) who studied the rhythm of spore liberation from sporophores. HyDE and WILLIAMs (1946) found that the spore amount of some fungi of genus Alternaria was at its highest in England in June-August, and that the number of airborne spores was corre- lated with air temperature. Of the weather elements measured in Helsinki, air humidity and precipitation in April-September seemed to be those most strongly affecting the diaspore deposition. In October-December, diaspore deposition was positively correlated (significance below 1 per cent) with the precipitation sum and the difference between maximum and minimum atmospheric pressures.

Table 3 gives the results of a sequential multiple regression analysis of the interdependence of weather elements and diaspore deposition in Helsinki. The weather elements for the analysis were selected on the basis of a correlation analysis. The mean air temperature of the last 5 days before the moment of measurement, at 2 metres above ground level in the forest, best explained the variations in the diaspore deposition during the whole year. The next best independent variables were precipiation and the difference between the maximum and minimum atmospheric pressure during the observation day. But all three weather elements together explained only 12.9 per cent of the variation in diaspore deposition. In January-March the best explanation was given by precipitation. In April-May air humidity, the differences between the maximum and minimum atmospheric pressure, the precipitation and wind velocity of the observation day together explained 47.3 per cent of the variations in diaspore deposition. In June-September the precipitation sum, air temperature on open site at a height of 2 metres, and the difference between the maximum and minimum atmospheric pressure together explained 14.1 per cent of the variation. In October-December the difference between maximum and minimum air pressure, air humidity and wind velocity provided the most important explanations.

In connection with the main study, the diaspore deposition in the forest in $\mathrm{Hel}$ sinki was investigated on July 31 to August 1 at ground level and at a height of 10 metres. From 21 to 01 o'clokc in the night the diaspore deposition at 10-metres was greater, but during the other hours of the observation day smaller, than at ground level. On June 26-27 the diaspore deposition around the Myllypuro water tower in Helsinki was considerably more profuse at ground level than at a height of $56 \mathrm{~m}$, and on July 
Table 3. Combinations of the weather elements best correlated with the total settling of diaspores in Helsinki 1968.

\begin{tabular}{|c|c|c|c|c|}
\hline Time of the year & $\begin{array}{l}\text { Weather element } \\
\text { or combination }\end{array}$ & $\mathrm{R}^{2}$ & 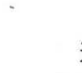 & $\begin{array}{l}\text { t-value and } \\
\text { s significance }\end{array}$ \\
\hline \multirow[t]{3}{*}{ The whole year } & 10 & 0.075 & & $6.37+++$ \\
\hline & 10,4 & 0.113 & $\begin{array}{l}1 \\
4\end{array}$ & $\begin{array}{l}6.05+++ \\
4.63+++\end{array}$ \\
\hline & $10,4,9$ & 0.129 & $\begin{array}{l}1 \\
4 \\
9\end{array}$ & $\begin{array}{l}6.76+++ \\
5.24+++ \\
-3.03++\end{array}$ \\
\hline Jan. 3 - Mar. 28 & 4 & 0.078 & & $2.81++$ \\
\hline \multirow{4}{*}{ Apr. 3-May 30} & 12 & 0.143 & & $-3.56+++$ \\
\hline & 12,9 & 0.236 & $\begin{array}{r}12 \\
9\end{array}$ & $\begin{array}{r}-3.23++ \\
3.02++\end{array}$ \\
\hline & $12,9,4$ & 0.3 .57 & $\begin{array}{r}12 \\
9 \\
4\end{array}$ & $\begin{array}{r}-3.59+++ \\
4.76+++ \\
3.72+++\end{array}$ \\
\hline & $12,9,4,8$ & 0.473 & $\begin{array}{r}12 \\
9 \\
4 \\
8\end{array}$ & $\begin{array}{l}2.75++ \\
6.00+++ \\
5.62+++ \\
-4.01++\end{array}$ \\
\hline \multirow[t]{3}{*}{ Jun. 5 - Sep. 26} & & 0.096 & & $4.55+t+$ \\
\hline & 4,1 & 0.135 & $\begin{array}{l}4 \\
1\end{array}$ & $\begin{array}{l}4.40+++ \\
2.93++\end{array}$ \\
\hline & $4,1,9$ & 0.141 & $\begin{array}{l}4 \\
1 \\
9\end{array}$ & $\begin{aligned} & 4.05+++ \\
& 2.65++ \\
- & 1.19\end{aligned}$ \\
\hline \multirow[t]{3}{*}{ Oct. 2 - Dec. 19} & 9 & 0.079 & & $3.34+++$ \\
\hline & 9,13 & 0.107 & $\begin{array}{r}9 \\
13\end{array}$ & $\begin{array}{l}3.54+++ \\
2.00+\end{array}$ \\
\hline & $9,13,7$ & 0.121 & $\begin{array}{r}9 \\
13 \\
7\end{array}$ & $\begin{aligned} & 3.81+++ \\
& 1.55 \\
- & 1.46\end{aligned}$ \\
\hline
\end{tabular}

$\mathrm{R}^{2}=$ coefficient of determination. For other explanations see Table 2.

17 -18 it was again more profuse at ground level than at 56 metres. On July 3-4 and July $24-25$ the diaspore depositions in Helsinki at ground level in the forest and on the open site were compared. On both occasions, the deposition was considerably more profuse on the open site than in the forest. On June 5-6 and 26-27 diaspore depositions were observed at the Kalbådagrund lighthouse in the Gulf of Finland. During both 24-hour observation days the total diaspore deposition on the sea in the Gulf of Finland was scantier than in the forest in Helsinki. Agar substrates were exposed on August 14-15 and October $2-3$ in the forest in Helsinki some $40 \mathrm{~cm}$ above ground level so that diaspores were caught from above, from below, and from the north, south, east and west. The largest deposition was recorded from above, the smallest from below, but the amount of deposition varied greatly according to the time of day or night. 


\section{Discussion and conclusions}

Agar substrates developed for studies of the $F$. annosus fungus were used in this investigation. The number of root rot fungus calonies was counted from these substrates for the $F$. annosus study (Kallio 1970), and the number of other, unidentified fungal calonies for the present study. According to the authors who developed these agar substrates, a number of fungi will not grow on them at all. Therefore, in evaluating the results, the limitations of the method described above must be borne in mind. The results, however, probably provide a general idea of the diaspore deposition in Finland, on which subject no previous information seems to be available.

The following conclusions can be dreawn on the basis of the study:

1. Diaspore deposition was scantier in North Finland than in South Finland.

2. Deposition was most profuse in the late summer and autumn, scantiest in the winter.

3. Deposition was more profuse in an open place than in the forest. In the summer, it was often more profuse in the forest during the night than day. Deposition decreased from ground level upward. On open sea deposition was scantier than over land.
4. Weather elements and diaspore deposition had mutual correlations. The most distinct of these, over a deposition period of one year, were the positive correlations with air temperature and precipitation. During the period of profuse deposition in JuneSeptember the correlation with precipitation was highest. According to sequential multiple regression analysis the variation in diaspore deposition in the course of a whole year was best explained by the air temperature of the last 5 days precending the observation day, measured at 2 metres above ground level near the place of recording the diaspore deposition. The variations in deposition, during the season of profuse dispersal from June to September, were best explained by precipitation and after that by air temperature.

\section{Acknowledgements}

Most valuable statistical help was given by $\mathrm{Mr}$. Juha Kasanen, M. Sc., of the Helsinki University Computer Centre. The personnel of the University of Helsinki, Department of Plant Pathology assisted me in many ways. I received financial support from the Foundation for the Research of Natural Resources in Finland, the National Research Council for Agriculture and Forestry and the University of Helsinki. My gratitude is due to all of them.

\section{REFERENCES}

Bernstein, T. B. \& Fernberg, S. M. 1942: Airborne fungus spores. A five-year survey of daily mold spore content of Chicago air. - J. Allergy 13: 231-247.

Dimitri, L. 1963: Untersuchungen über die Ausbreitung von Fomes annosus (Fr.) Cooke. - Phytopath. Z. 48: 349-369.

Drummond, D. B. \& BRetz, T. W. 1967: Seasonal fluctuations of air-borne inoculum of Fomes annosus in Missouri. - (Abstr.) Phytopath. 57: 340 .

Durham, O. C. 1938: Incidence of air-borne fungus spores. II. Hormodendrum, Alternaria, and rust spores. - J. Allergy 10: 40-49.

Feinberg, S. M. \& Little, H. T. 1936: Studies on the relation of microorganisms to allergy. III. A year's survey of daily mold spore content of the air. - J. Allergy 7: 149155.

Gregory, P. H. 1945: The dispersion of air-borne spores. - Trans. Brit. Mycol. Soc. 28: $26-72$.

- 1952a: Fungus spores. - Trans. Britt. Mycoll. Soc. 35: $1-18$.

- 1952b: Spore content of the atmosphere near the ground. - Nature (London) 170: $475-477$.
- 1961: The microbiology of the atmosphere. - 251 pp. London-New York.

- \& Sreeramulu, T. 1958: Air spora of an estuary. - Tanrs. Brit. Mycol. Soc. 41: $145-156$

Hansen, E. C. 1882: Undersøgelser over de organismer, som till forskjellige tider af aaret findes i luften i og omkring Carlsberg, og som kunne udvikle sig ølurt. - Medid. Carlsberg Lab. 1: 381-415. Kjøbenhavn.

Harvey, R., Hodgkiss, I. J. \& Lewis, P. N. 1969: Air-spora studies at Cardiff. II. Chaetomium. - Trans. Brit. Mycol. Soc. 53: 269 278.

Hirst, J. M. 1953: Changes in atmospheric spore content: Diurnal periodicity and the effects of weather. - Trans. Brit. Mycol. Soc. 36: $375-393$.

- , Stedman, O. J. \& Hogg, H. H. 1967a: Long-distance spore transport: Methods of measurement, vertical spore profiles and the detection of immigrant spores. - J. Gen. Microbiol. 48: 32:9-355.

- , Stedman, O. J. \& Hurst, G. W. 196.7b: Long-distance spore transport: Vertical sections of spore clouds over the sea. J. Gen. Microbiol. 48: 357-377. 
Hodgkiss, I. J. \& Harvey, R. 1969: Spore discharge rhythms in Pyrenomycetes. VI. The effects of climatic factors on seasonal and diurnal periadicities. - Trans. Brit. Mycol. Soc. 52: 355-363.

Hyde, H. A. \& Williams, D. A. 1946: A daily census of Alternaria spores caught from the atmosphere at Cardiff in 1942 and 1943. Trans. Brit. Mycol. Soc. 29: 78-85.

- 1953: The incidence of Cladosporium herbarum in the outdoor air at Cardiff, 194950. - Trans. Britt. Mycol. Soc. 36: 260 266.

KALlio, T. 1965: Tutkimuksia maannousemasienen leviämisbiologiasta ja torjuntamahdollisuuksista Suomessa. Summary: Studies on the biology of distribution and possibilities to control Fomes annosus in southern Finland. - Acta For. Fenn. 78(3): 1-21.

- 1970: Aerial distribution of the root-rot fungus Fomes annosus (Fr.) Coolke in Finland. - Acta For. Fenn. 1.07: 1-55.

Kuhlman, E. G. 1966: Recovery of Fomes annosus spores from soil. - (Abstr.) Phytopath. 56: 885

- \& Hendrix, F. F., Jr. 1962: A selective medium for the isolation of Fomes annosus. - Phytopath. 52: 1310-1311.

Mrller, O. K., Jr. 1960: The distribution of Fomes annosus (Fries) Karst. in New Hampshire red pine plantations and some observations on its biology. - Caroline A. Fox Res. Dem. Forest Bull. No. 12. 25 pp. Concord, N.H.

Molin, N. 1957: Om Fomes annosus spridningsbiologi. Summary: A study on the infection biology of Fomes annosus. - Medid. Statens Skogsforskn. Inst. 47(3): $1-36$

NilsBy, I. 1949: Allergy to moulds in Sweden. A botanical and clinical study. - Acta Allergologica 2: $57-90$.

PADY, S. M. \& Kramer, C. L. 1969: Periodicity in ascospore discharge in Bombardia. Trans. Brit. Mycol. Soc. 53: 449-454.

- , Kramer, G. L. \& Clary, R. 1969a: Aeciospore release in Gymnosporangium. Can. J. Boit. 47: 1027-1032.

- , Kramer, C. L. \& Glary, R. 1969b: Periodicity in spore releas ein Cladosporium. - Mycologia 61: 87-98.
PathaK, V. K. \& PAdy, S. M. 1945: Numbers and viability of certain airborne fungus spores. - Mycologia 57: 301-310.

RenNerfelt, E. 1947: Några undersökningar över luftens halt av svampsporer. Summary: Some investigations into the fungus diaspore content of the air. - Sv. Bot. Tidskr. 41: $283-294$

Reynolds, G. \& Wallis, G. W. 1966: Seasonal variations in spore deposition of Fomes annosus in coastal forests of British Ciolumbia. -Can. Dep. Agric. Bi-Month. Res. Notes 22(44: 6-7.

RICH, S. \& WAGgoner, P. E. 1962: Atmospheric concentration of Cladosporium spores. Science 137 (3534): 962-965.

Richards, M. 1954a: Atmospheric mold spores in and out of doors. - J. Allergy 25: 429 439.

- 1954b: Seasonal periodicity in atmospheric mould spore concentrations. - Acta Allergologica 7: $357-366$.

RishbetH, J. 1951: Observations on the biology of Fomes annosus, with particular reference to Eeast Anglian pine plantations. II. Spore production, stump infection, and saprophytic activity in stumps. - Ann. Bat. N.S. 15 (57): $1-21$.

Rstrup, O. 1908: Nogle undersøgelser over luftens indhold af svampekim. - Botanisk Tidsskrift 29(1): 32-41.

Sinclatr, W. A. 1964: Root- and butt-rot of conifers caused by Fomes annosus, with special reference to inoculum dispersal and control of the disease in New York. - N. Y. State Coll. Agric. Ithaca, Mem. 391. 54 pp. N. Y.

Walkey, D. G. A. \& Harvey, R. 1968: Spore discharge rhythms in Pyrenomycetes. IV. The influence of climatic factors. - Trans. Brit. Mycol. Soc. 51: 779-786.

Yde-Andersen, A. 1961: Om den årstidsbetingede variation $\mathrm{i}$ hyppigheden af stødfladeinfektioner med luftbårne Fomes annosus-sporer hos rødgran. Summary: On the seasonal variation in the incidence of stump surface infection by air-borne F. annosus spores in Norway spruce. - Dansk Skovfor. Tidskr. 46: $139-158$. 